\title{
315 液滴火炎構造に及ぼす雾囲気中の水蒸気および燃料蒸気濃度の影響
}

Effects of Humidity and Fuel Vapor Concentration in the Gaseous Stream on a Droplet Flame Structure

○学 鈴木 敦 （阪府大院） 正 瀬川大資（阪府大工）

正 角田 敏一（阪府大工）

Atsushi SUZUKI, Graduate School, Osaka Prefecture University, 1-1 Gakuen-cho, Sakai, Osaka Daisuke SEGAWA, Osaka Prefecture University

Toshikazu KADOTA, Osaka Prefecture University

\begin{abstract}
An experimental study was performed to clarify the flame structure of a burming fuel droplet. $\mathrm{OH}$ concentration distributions were measured along diametrical line passing through the front stagnation point of a fuel droplet flame in the gaseous stream. The laser induced fluorescence was applied for the measurement of $\mathrm{OH}$ concentration distributions. An Nd:YAG laser-pumped pulsed dye laser emitting monochromatic radiation at a wavelength of $283.62 \mathrm{~nm}$ was used as the light source for these measurements. The results showed that the maximum of $\mathrm{OH}$ concentration was located near the flame front. An increase in the relative humidity in the gaseous stream caused the decrease of $\mathrm{OH}$ concentration. The increase in benzene vapor concentration in the gaseous stream around a benzene droplet flame causes the increased maximum $\mathrm{OH}$ concentration and the outward extension of the region in which $\mathrm{OH}$ is present.
\end{abstract}

Key words : Liquid Fuel, Droplet Flame, OH, Laser Induced Fluorescence

\section{1. 緒言}

燃焼中の液滴周囲に形成される火炎の構造は, 内部に存在 する液滴の蒸発現象を支配するだけでなく, 放射や火炎から 排出される化学種生成と密接な関係があるため, その解明が 要望されている. 液滴の然焼現象についてはこれまでに多く の実験結果が報告されているが, 燃焼特性値の決定に力点が 置かれてきており，例えば燃焼速度定数の測定, 液滴温度測 定などが行われている.しかしながら，液滴火炎の構造に関 する測定データは少なく, 実験条件も限られている.このよ うな観点から，著者らは一様空気流中に形成される液滴火炎 内の $\mathrm{OH}$ 濃度測定を行い(1)，さらに液滴火炎構造に及ほす燃 料性状の影響について調へた (2)。本報では，水蒸気または㜣 料蒸気が添加された一様空気流中に形成される単一液滴の 火炎を対象に，その前方よどみ点を通る半径方向の $\mathrm{OH}$ 濃度 分布をレーザ誘起喾光法を利用して測定し, 液滴火炎構造に 及ほす雾囲気中の水蒸気および燃料蒸気濃度の影響を調べ た.

\section{2. 実験装置}

図 1 に実験装置の概略を示す.実験装置は, 以前の研究(1)(2) に使用したものと, 空気供給系の一部を除き同様な構成であ る. レーザ誘起営光法の励起光源には, Nd:YAG パルスレー ザ励起の色素レーザ（Spectron, SL803+SL4000）を用いた. 波長は OH の吸収波長の 1 つである $283.65 \mathrm{~nm}$ に調整した. レーザビーム光は球面レンズ, ピンホールを経て液滴火炎に 照射される。 $\mathrm{OH}$ は, $\mathrm{A}^{2} \Sigma(\mathrm{v}=0) \rightarrow \mathrm{X}^{2} \Pi(\mathrm{v}=0)$ 準位間の電子エネ ルギー遷移により営光を発する.

その蛍光は, 照射ビーム光に対して $90^{\circ}$ の方向から, 球面 レンズで集光されバンドパスフィルタ（中心波長 $306.5 \mathrm{~nm}$, 半值幅 $13.7 \mathrm{~nm}$ ）を経て, 光電子增倍管（浜松ホトニクス, R928）で検出される. 視野は直径 $100 \mathrm{~mm}$ とした.

光電子增倍管の出力はデジタルストレージオシロスコー プに記録される. 視野内の $\mathrm{OH}$ 濃度が, レーザの発振 1 回に 対する蛍光強度の経時変化での最大值に比例するとして, 記 録されたデータを処理した.

営光の測定と同時に，照射ビーム光に対して $270^{\circ}$ の方向 より,ビデオカメラによる液滴火炎像の直接撮影も行った. 拡大された液滴像より, 撮影も行った. 拡大された液滴像よ り, 初期液滴直径, 液滴表面と火炎（青炎）との位置の時間
変化が測定される. また, これらの測定結果と, あらかじめ 設定した照射レーザ光と測定視野の位置, 蛍光強度のデータ を対応させることにより, 液滴火炎内の $\mathrm{OH}$ 濃度分布が得ら れる。

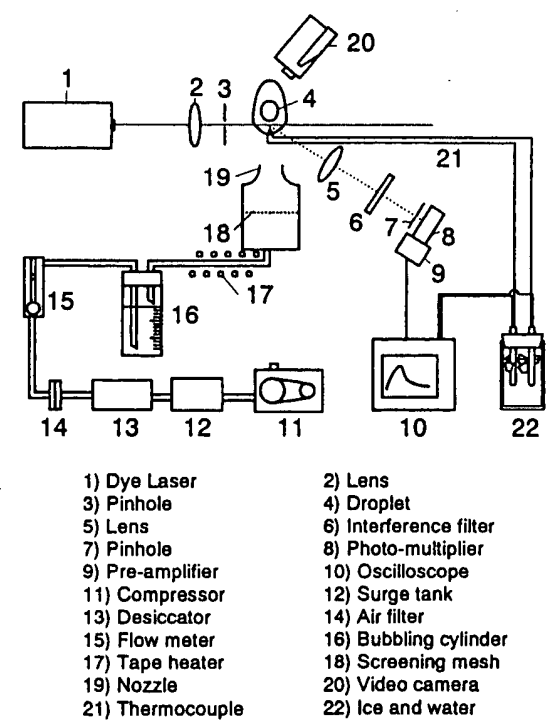

Fig. 1 Experimental apparatus

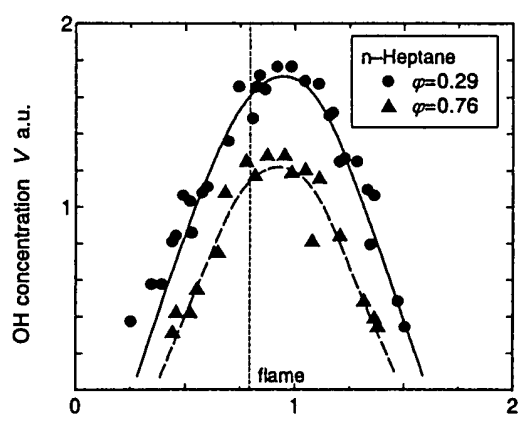

Distance from droplet surtace $y \mathrm{~mm}$

Fig. $2 \mathrm{OH}$ concentration distribution ( $\mathrm{n}-$ Heptane) 


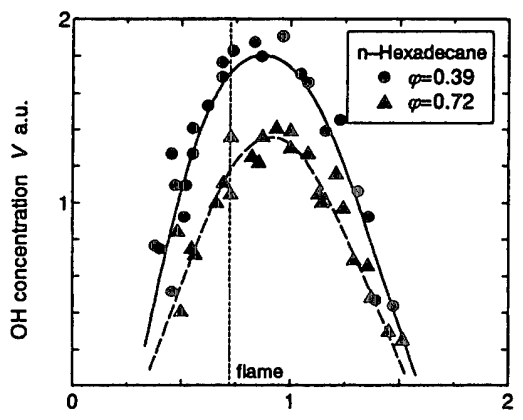

Distance from droplet surface $y \mathrm{~mm}$

Fig. $3 \mathrm{OH}$ concentration distribution ( $\mathrm{n}-$ Hexadecane)

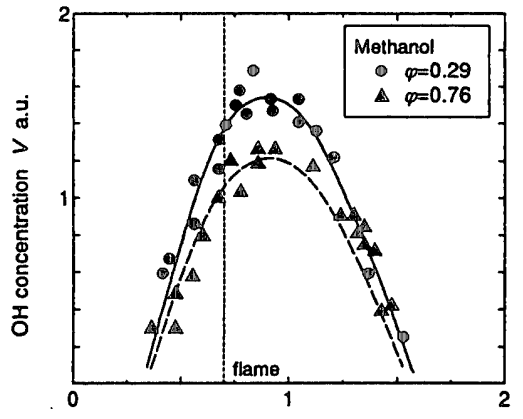

Distance from droplet surface $y \mathrm{~mm}$

Fig. 4 OH concentration distribution (Methanol)

微速 $(0.4 \mathrm{~m} / \mathrm{s})$ 空気流の形成には四分円ノズルを用いた. 空 気は, コンプレッサからサージタンク, デシケータ, エアフィ ル夕, フロート式空気流音計, バブリング容器を経て, 四分 円ノズルに供給される.エアフィルタの孔径は $5 \mu \mathrm{m}$ とした. バブリング容器内の水または撚料の減少速度と空気流舅か

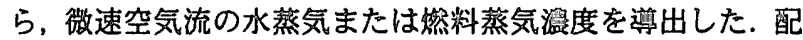
管に巻いたテープヒータにより, 空気温度を $40^{\circ} \mathrm{C}$ に保った.

線径 $0.25 \mathrm{~mm}$ の石英系の先端球状部に，液滴を留垂した。 供試燃料には, $\mathrm{n}$ ーヘプタン, nーヘキサデカン, メタノール, ベンゼンを用いた. 初期液滴直径は $2.0 \mathrm{~mm}$ とした.

\section{3. 笑験結果方よび婆察}

図 2〜図 4に水蒸気添加気流中に㯰かれた nーヘプタン, n 一ヘキサデカンおよびメタノール液滴火炎における OH溜度 分布を示す. 図の横朝は，前方よどみ点を通る半径方向の， 液滴表面を原点とした距離としている．また，ピデオカメラ の映像より得られた肓炎外緑の位掼を，破線で示している。 すべての供試燃料について共通した傾向を示し，OH 溜度は， 液滴表面から離れるにしたがって単調に上昇し，䃾炎のやや 外側で最大值を示して減少している。 OH 飻度分布砷状およ び最高祳度が現れる位置は相対湿度 $\varphi$ によってほとんど変化 しないことがわかる. また，青炎外緑位圆も変化が見られな かった。 しかしながら， OH 溜度の最高值は相対湿度の上昇 とともに低下する. 液滴火炎温度も同時に低下している可能 性が考えられるが，その詳細の把握には例えば火炎領域の非 接触温度計測を行うことなどが必要となり，それらが今後の 課題と位置つ゚けられる。

図 5 に OH 濃度の最大值に及ぽす空気流の相対湿度の影餐 を示す．ただし，各条件における OH 鼬度分布形状を曲線近 似した上で，その曲線の頂点に対応する値を最大值 $V \max$ 之 定義している．さらに，各燃料について，相対湿度 $\varphi=0.39$ の場合の最大值 $V$ max 大值を，図の縦軸としている，いずれの場合にも，相対湿度

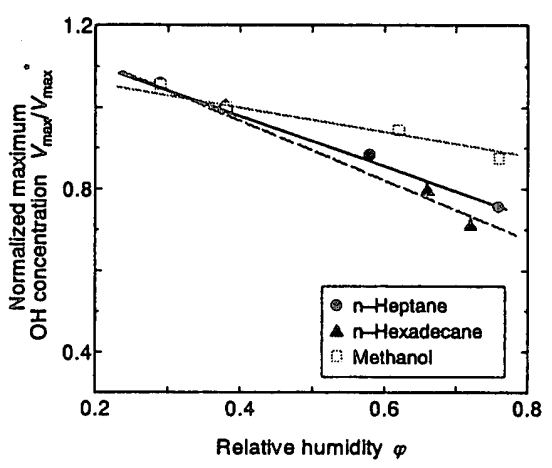

Fig. 5 Effect of ambient relative humidity on maximum $\mathrm{OH}$ concentration

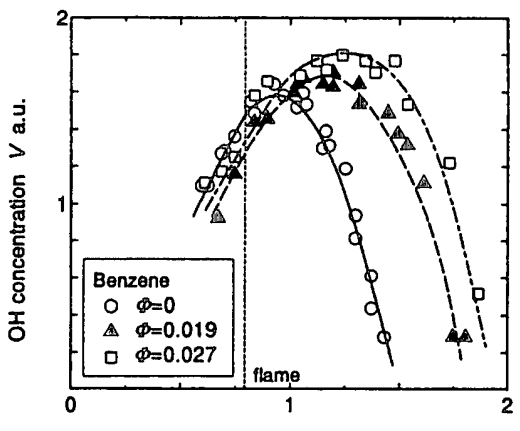

Distance from droplet surface $y \mathrm{~mm}$

Fig. $6 \mathrm{OH}$ concentration distribution in benzene droplet flame in the gaseous mixture of dry air and benzene vapor

の上昇とともに, $\mathrm{OH}$ 浱度最大值は直線的に減少している. さらに, $\mathrm{n}$ ーヘプタンと $\mathrm{n}$ ーヘキサデカンの結果を比較すると, その減少傾向は同様となっている. しかしながら, メタノー ルの場合については, $\mathrm{n}$ ヘヘフタンや $\mathrm{n}$ ーヘキサデカンの場合 と異なり，減少がやや䌊やかとなっている，つまり，相対湿

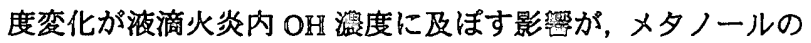
場合には他と比べてやや弱くなっている。

図6にベンゼン蒸気添加気流中に置かれたベンゼン液滴火 炎における OH浪度分布を示している. 空気 $1 \mathrm{~kg}$ 中に含まれ

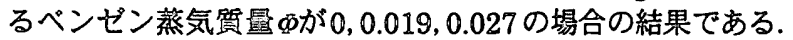

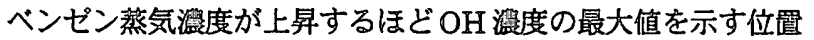
は外側へ移動するとともに OH の存在簤囲は外側へ広がる. ま たベンゼン蒸気泒度が上昇するほど OH 搌度の最大值は上昇す る.また，ベンゼン億気溜度による青炎外緣位置の変化は見 られなかった。

4. 绻曾

(1)OH 派度は，液滴表面から離えるにしたがって単調に增加 し，学炎外緑のやや外側で最大值を示して低下する。

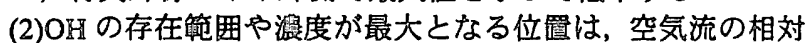
湿度の影響を受けない。

(3) $\mathrm{OH}$ 浱度の最大值は, 空気流の相対湿度の上昇とともに直 線的に低下するが，その低下傾向は燃湖により若干異なる。

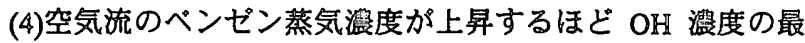
大値は上昇し, $\mathrm{OH}$ の存在節囲は外側へ広がる.

文献

(1)鈴木・瀬川・角田, 第 40 回燃焼シンポジウム講演論文集, pp.297-298(2002)

(2)鈴木・瀬川・角田, 日本機械学会関西支部第 78 期定時総会 講演会丵演論文集, pp.3-29-30(2002) 